\title{
THE INFLUENCE OF THE CHROMATIC CONTRAST CHANGE OF DIGITAL PRINTS ON THE MEASURED CONTRAST SENSITIVITY FUNCTION
}

Milana Ž Sadžakov*, Igor Đ Karlović

Faculty of Technical Sciences, Department of Graphic Engineering and Design, Novi Sad, Serbia

The colour appearance of a stimulus is not independent of its spatial and temporal characteristics. The prints in the graphic arts are both colorimetrically and spatially variable surfaces due to the use of halftoning with different inks. The spatial and temporal characteristics of the human visual system are typically explored through the measurement of contrast sensitivity functions. Contrast sensitivity functions (CSFs) in vision science are analogous to modulation transfer functions (MTFs) in imaging science. The contrast sensitivity function (CSF) is essential for the detail perception and it is one of the main components of visual models and metrics. CSF is a well researched but never the less, CSF has not been widely researched in terms of application in hardcopy prints made by digital printing systems, but mainly on colour displays. The aim of this paper was to determine if there is any similarity between two types of reducing contrast: (1) type $\mathrm{C} 1$ where two opponent colours get mixed; and (2) type C2 where the colour saturation is reduced. A group of 15 subjects evaluated a printed test form containing frequency and contrast variable elements using magnifying glass. The results showed that the eye is similarly sensitive to both types of the contrast change. The plots of reducing saturation (C2) showed a similar shape like C1 but had slightly lower sensitivity, especially in the red-green contrast. This can be useful for color difference metrics cut-offs and for designers in determining which details and contrasts do not have to be used as they cannot be seen by the final observer.
(ORIGINAL SCIENTIFIC PAPER) UDC 681.784.4:535.6
Keywords: contrast sensitivity function, CSF, chromatic contrast, saturation

\section{Introduction}

The contrast sensitivity function (CSF) has been a part of many studies from over a few decades ago. The sensitivity of human eyes was interesting to many areas of science like ophthalmology [1], physiology [2], and optics [3]. The eye sensitivity limitations improved color halftoning methods [4], digital image quality on screens [5,6], and the image quality evaluations [7]. The CSF measures the sensitivity of the human visual system to linear contrast as a function of spatial frequency. Sensitivity is defined as the reciprocal value of the contrast threshold or as the minimum amount of contrast necessary to evoke a response. The contrast is not well defined when the contrast threshold or sensitivity is measured on chromatic stimuli that does not contain luminance information. It is known that luminance CSF is characterized as a bandpass shape, whereas the chrominance CSF for both red-green and blue-yellow are low-pass [8]. Generally, eyes show higher sensitivity on the achromatic contrast than on the chromatic contrast for the same spatial frequency. However, for very low spatial frequency content, chromatic contrasts are actually more perceptible than achromatic [9]. M.J. Luque at al. [10] stated in their study that the achromatic filter is peaking around 3 to 4 cycles per degree (cpd), with a cutoff frequency at around $40 \mathrm{cpd}$, whereas the chromatic red-green and blue-yellow filters have cutoff frequencies at around 12 and 10 cpd, respectively. There have been several studies on measuring chromatic CSFs [2,9,11,12]. Kil Joong Kim at al. [11] measured the frequency range of the sine gratings that varied from 0.25 to $8 \mathrm{cpd}$ for chromatic stimuli. They created the stimuli for following color directions: red to green, yellow-green to violet, dark-green to light-pink, and dark-yellow to light-blue. The stimuli were observed with a natural pupil on the screen set to the mean luminance level. They tried to capture the effect of luminance on contrast detection and their measurements showed a significant drop in sensitivity with luminance, but little change in the shape of the CSF. Hirai et al. [12] measured spatio-velocity for two chromatic CSF at $38.5 \mathrm{~cd} / \mathrm{m}^{2}$ for red to green and at $12.2 \mathrm{~cd} / \mathrm{m}^{2}$ for blue to yellow, all in the range $0.5-8 \mathrm{cpd}$. The data was used to model chromatic spatio-velocity contrast sensitivity, which will extend the S-CIEL ab quality metric to the temporal domain. Because of the application, the stimuli were observed under natural

\footnotetext{
*Author address: Milana Sadžakov, Department of Graphic engineering and design,

Faculty of Technical Sciences, University of Novi Sad, Trg Dositeja Obradovića 6, 21000 NoviSad, Serbia

E-mail: milanas3@uns.ac.rs

The manuscript received: May, 12, 2014.

Paper accepted: Jul, 15, 2014.
} 
conditions. The stimuli were measured for a single luminance level. Fairchild at al. [9] measured the achromatic and chromatic contrast on threshold and suprathreshold levels to check if they are similar enough, so they can use the same set of spatial filters for both threshold levels during the measurement of color difference. They used noise patterns for the following colour directions: black-white, yellow-blue, lime-purple, orange-cyan, and red-green. They proved opponent color dimensions orthogonality as very important. Green [2] measured the CSFs at different luminance levels where colored sine-grating was shown on a background of different colors. The viewing conditions were strictly controlled but also differed from normal viewing by following: artificial and dilated pupil, monocular viewing and the stimuli were corrected for chromatic aberrations with lens. The resulting CSFs had a band-pass shape typical for achromatic CSF.

In this paper it was found that there is a similarity between two types of a reducing contrast, the one where two opponent colours get mixed and the one where colour saturation is reduced. The results show that the eye is slightly less sensitive to the contrast change by saturation reduction. The data obtained by the aforementioned research can be used with the appropriate application to the design phase of the graphic arts production. Considering the limitations of the marking engine of the digital printing system, the used materials and the CSF function of the human eye, more appropriate designs can be prepared for printing, regarding chromatic contrast values and spatial variations.

\section{Methods and materials}

In this experiment the modified RIT contrast resolution target [13] made for the examination of printing systems, to make chromatic (both red-green and blue-yellow) contrast sensitivity target was used. It was changed by two types of contrast reducing. In the first, the gratings were changed from the maximum contrast to the contrast reduced by mixing two opponent colors (type C1), and in the second the gratings were placed on a neutral (50\%) gray background and the contrast was reduced by reducing their opacity (type C2). In other words, the contrast was reduced by reducing color saturation. The aim of this research was to determine if there is any similarity between C1 and C2 types of contrast. Each target is consisted of $10 \times 10$ arrays where the lines and the contrasts are varying stepwise over a logarithmic range. The dimension for a single array was $5 \times 5 \mathrm{~mm}$. The range of spatial frequencies was from $0.27-3.42 \mathrm{cpd}$. There test forms were printed with the resolution of $300 \mathrm{dpi}$ on the printing machine Xerox 5300. For the array dimension of $5 \mathrm{~mm}$, the highest spatial frequency that can be printed on this printing machine is $3.42 \mathrm{cpd}$ or 6.3 cycles per mm. The printed paper was Kunstdruck $115 \mathrm{~g} / \mathrm{m}^{2}$, both sided matt coated paper from the producer M-Real. The matt surface was used to prevent a specular light reflection. Targets were printed in a horizontal way regarding the direction of printing head movement, in the way that horizontal lines were extending in the direction of movement. The modified test form is presented in Figure 1.

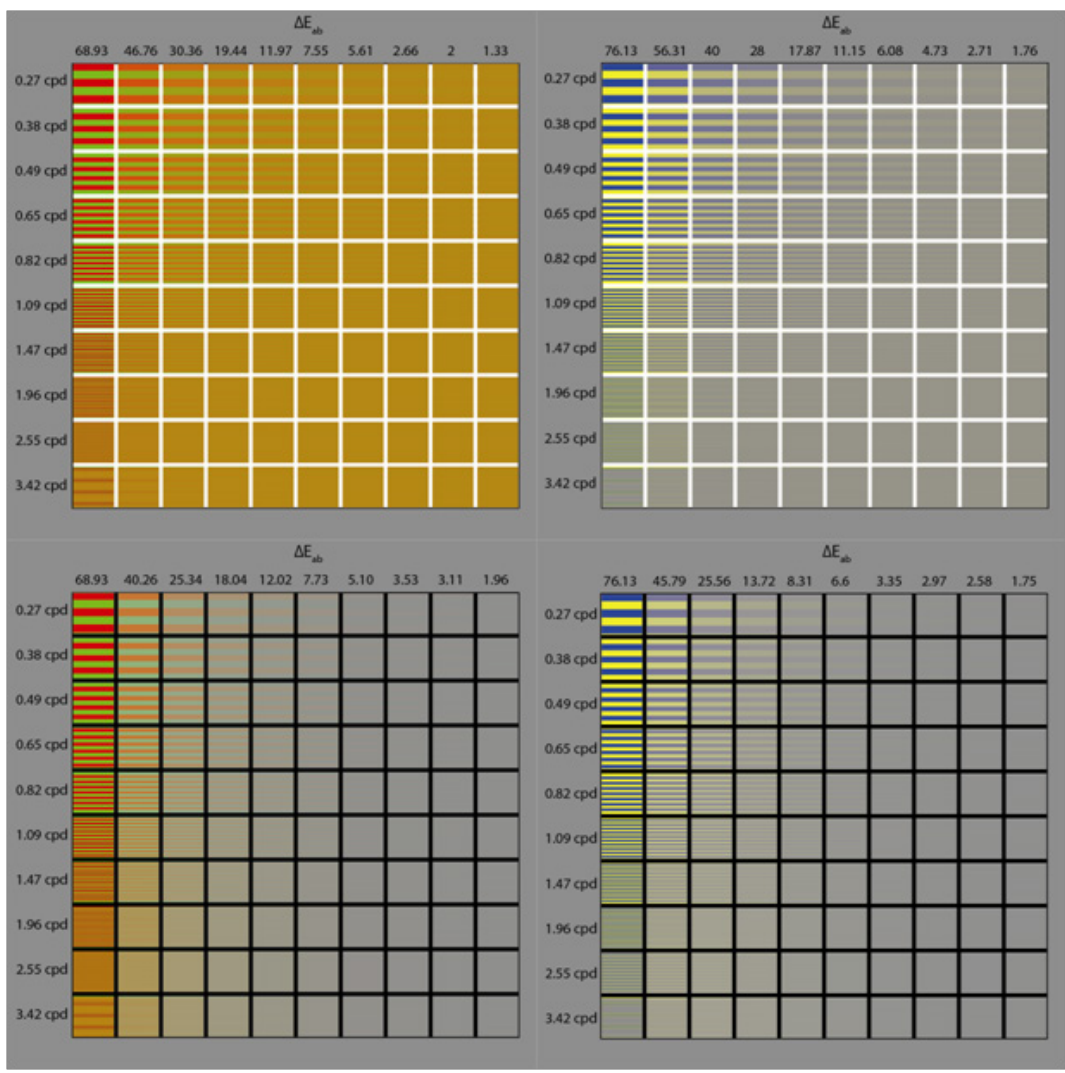

Figure 1. Test targets: top left- type $\mathrm{C} 1$ red-green, top right - type $\mathrm{C} 1$ blue-yellow, bottom left - type C2 red-green, bottom right - type C2 blue-yellow 
Fifteen subjects, 9 males and 6 females, having normal color vision were recruited to participate in this study. Their ages ranged from 22-35. All subjects were required to have superior color hue recognition ability, i.e. to scorelower than 20 for Farnsworth Munsell 100 hue color vision test. Targets were observed under controlled light D50 in Agile Radiant cabinet, at the same position, using a magnifier [13] of $8 x$ and the results were recorded for the lowest contrast where the subject still recognized the gratings. The observers used a $50 \%$ gray mask to isolate the array that was evaluated, to prevent the influence of other arrays. As the targets were seen vary closely under $8 x$ magnifier it caused eye fatigue so, before each evaluation, we suggested the subjects that they close the eye for a moment to arrest retina and avoid "filling in" arrays with lines that did not exist. Since the printed image was made from halftone dots, the subjects had to make a decision about the colour difference using magnifier, not only based on lines but on the dots that made those lines. That made the evaluation more difficult. The method of limits was used for the evaluation because of the types of targets. To present the contrast, we calculated the color difference as in [14] but we used $\Delta \mathrm{ClE}_{\mathrm{ab}} 2000$ as recommended by CIE $[15,16]$. The CSF was measured for $0.27,0.38,0.49,0.65,0.82,1.09,1.47,1.96,2.55$, $3.42[\mathrm{cpd}]$ spatial frequencies.

\section{Results and Discussion}

Figure 2 shows a difference in contrast for targets $\mathrm{C} 1$, where it can be seen that at greater frequencies the redgreen contrast is more discernible than the blue-yellow, as it was expected. Lower frequencies from 0.27-0.49 cpd showed similar discernibility for both contrasts. At frequency $0.65 \mathrm{cpd}$ the red-green contrast started to show better discernibility. The results even showed slightly better discernibility of the blue-yellow contrast in middle frequencies from $\sim 0.76 \mathrm{cpd}$ until $1.96 \mathrm{cpd}$ where both contrast showed the same discernibility. For frequencies greater than $1.96 \mathrm{cpd}$, red-green contrast showed remarkably higher discernibility.

Figure 3 shows a difference in contrast for targets $\mathrm{C} 2$. It is noticeable that the plot is similar to $C 1$, and that this kind of contrast also showed a greater drop in sensitivity for the blue-yellow contrast at greater frequencies than the red-green contrast. Unlike C1, plot C2 showed better discernibility of the red-green contrast than the blue-yellow in the range of lower frequencies. Contrasts showed the same discernibility in four points: (a) between 0.49 cpd and $0.65 \mathrm{cpd}$, (b) between $0.65 \mathrm{cpd}$ and $0.82 \mathrm{cpd}$, (c) on the value slightly greater than $0.82 \mathrm{cpd}$ and (d) on the value 1.96. Between the first (a) and second (b) point, slightly higher discernibility had the blue-yellow contrast, unlike plot $\mathrm{C} 1$. Between the second (b) and third (c) point, like on $\mathrm{C} 1$ plot, the blue-yellow contrast had higher discernibility than the red-green, but with slightly greater difference in values.

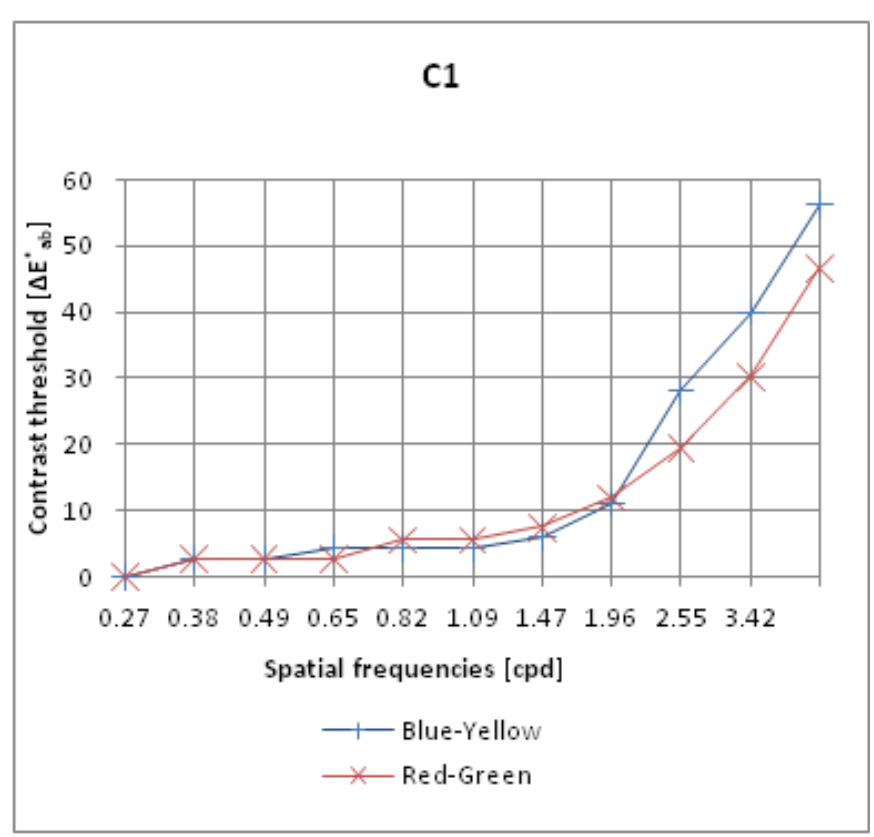

Figure 2. Difference in contrast for targets $C 1$

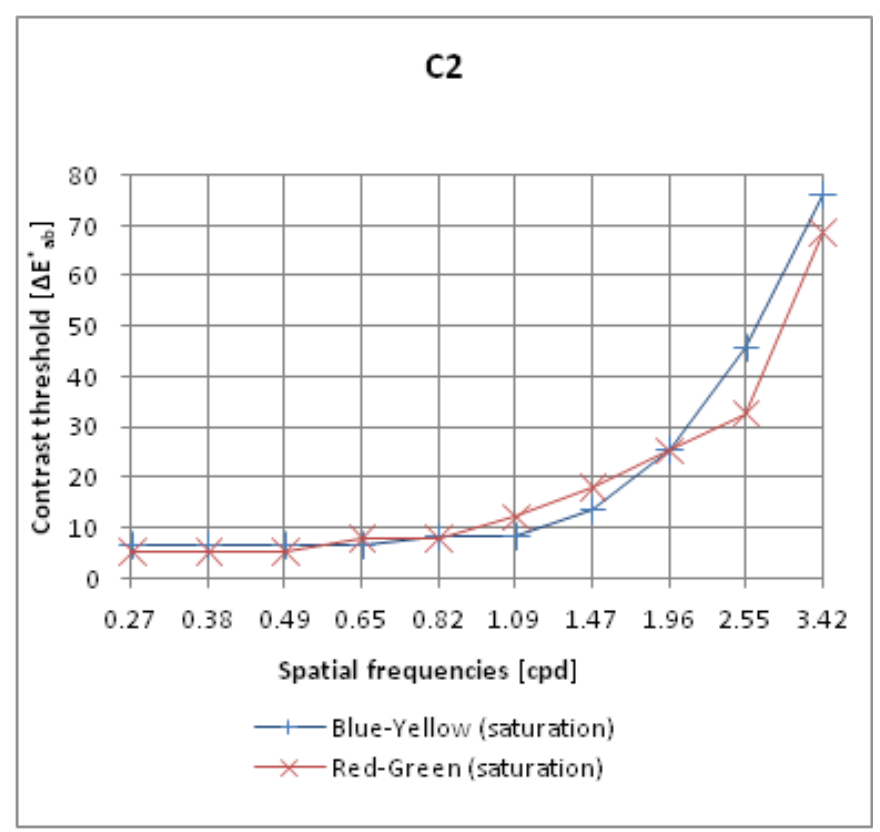

Figure 3. Difference in contrast for targets C2

Comparison between $\mathrm{C} 1$ and $\mathrm{C} 2$

Comparing $\mathrm{C} 1$ and $\mathrm{C} 2$ in the red-green contrast, it can be seen that plot lines have a similar shape, while C2 shows reduced discernibility. From the lowest frequencies until $0.82 \mathrm{cpd}$, the difference between these two lines appears similar. After that point the differences are increasing until $2.55 \mathrm{cpd}$ where they again are very close. The rest of the frequencies show a significantly greater drop in sensitivity for $\mathrm{C} 2$.

When compared $\mathrm{C} 1$ and $\mathrm{C} 2$ for the blue-yellow contrast, the results are a little bit different, even C2 still shows lower discernibility. The plots show two points with equal discernibility. The first (e) is between $1.47 \mathrm{cpd}$ 
and $1.96 \mathrm{cpd}$ and the second (f) is between $1.96 \mathrm{cpd}$ and $2.55 \mathrm{cpd}$. At frequency $1.96 \mathrm{cpd}$, C2 shows slightly greater discernibility. After point (f), C2 has a significantly greater drop in sensitivity than $\mathrm{C} 1$.

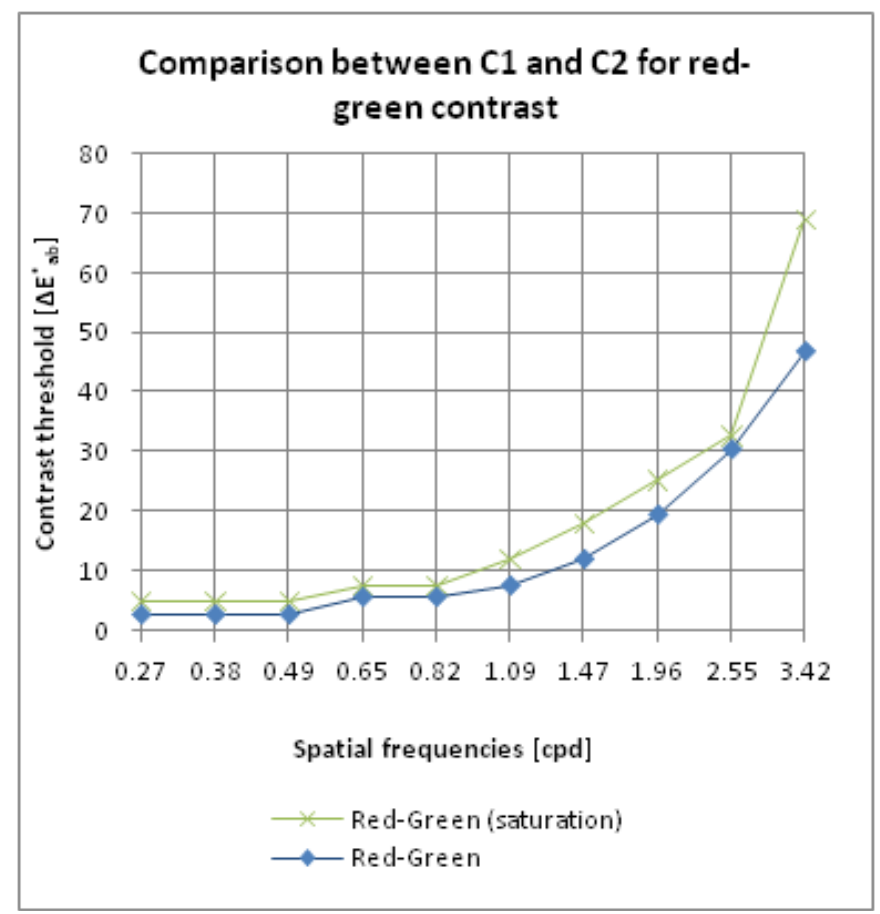

Figure 4. Comparison between $\mathrm{C} 1$ and $\mathrm{C} 2$ for red-green contrast

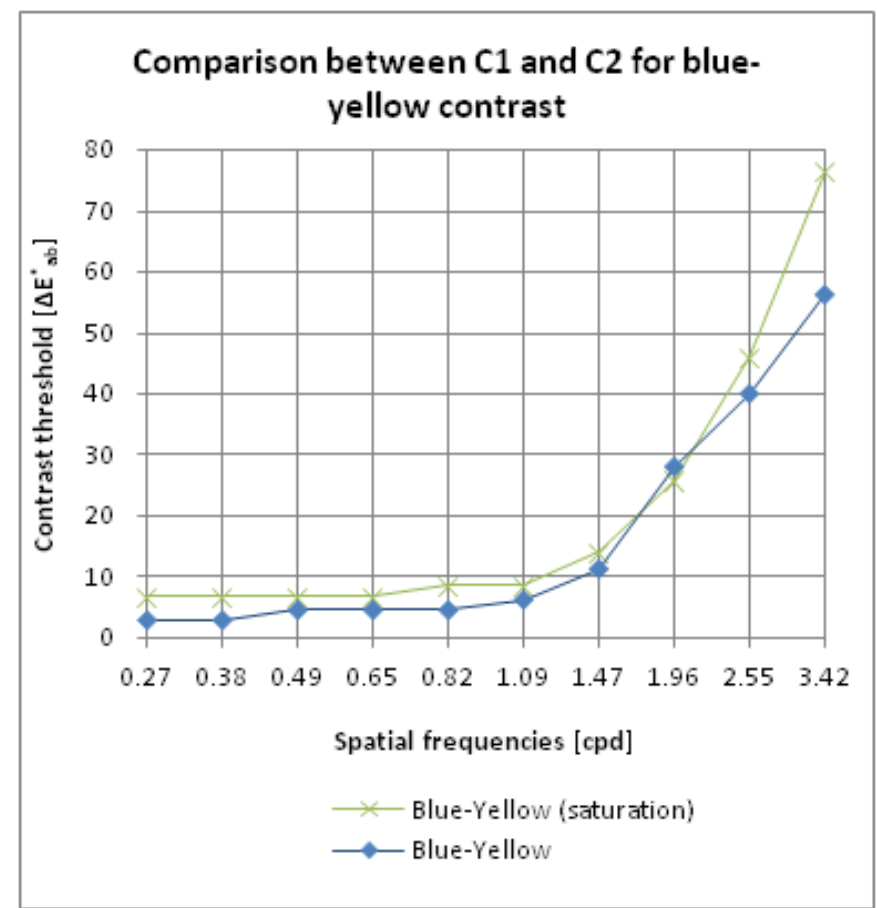

Figure 5. Comparison between $\mathrm{C} 1$ and $\mathrm{C} 2$ for blue-yellow contrast

\section{Conclusion}

The contrast is a difference between maximum and minimum luminance in a stimulus divided by the sum of the maximum and minimum luminances. This type of the contrast is called the achromatic contrast. The contrast can also be chromatic when opponent colours (red-green and yellow-blue) are used at constant luminance. A human eye is more sensitive to the achromatic contrast than to chromatic one at high spatial frequencies. The sensitivity of the chromatic contrast is low-pass which means that the eye cannot perceive fine chromatic details.

The main goal of this research was to investigate if there is any similarity between two types of the reducing contrast, the one where two opponent colours get mixed and the other where the colour saturation is reduced.

The results show that the eye is similarly sensitive to both contrasts. The plots of reducing saturation (C2) show a similar shape like $\mathrm{C} 1$ but have a slightly lower sensitivity, especially in the red-green contrast. This can be useful for colour difference metrics cut-offs and for designers to determine which details and contrasts do not have to be used as they cannot be seen.

Similarly to real images constructed from a great number of details, subjects needed to make a decision about the colour difference during the observation of halftone dots array. The experiment was conducted in controlled environment with special attention given to frequencies and contrast that subjects reported as problematic for making a decision regarding observing the colour difference.

As opposed to other researches where CRT/LCD monitors were used, in this experiment printed targets were used because we needed the results for a real printed image and not the results predicted by software and monitors.

In future work, the tendency is to measure the same spatial frequencies on greater arrays that can be perceived without a magnifier and to compare the obtained results with the results from this paper. It is also planned to analyze the contrasts obtained in this paper at higher frequencies, and on printed targets as well. The results will be compared with the ones predicted by S-CIE Lab calculations.

\section{Acknowledgements}

This work was supported by the Serbian Ministry of Science and Technological Development, Grant No.: 35027 "The development of software model for improvement of the knowledge and production in graphic arts industry".

\section{Abbreviations and symbols}

CSF - Contrast sensitivity function

MTF - Modulation transfer function 
CIE - Commission Internationale de l'Eclairage

RIT - Rochester Institute of Technology

\section{Reference}

[1] M. S., Banks, P.Salapatek(1978).Acuity and contrast sensitivity in 1-, 2-, and 3-month-old human infants. Investigative Ophthalmology \& Visual Science17(4), pp. 361-5

[2] D., Green(1968). The contrast sensitivity of the colour mechanisms of the human eye, The Journal of physiology 196, pp. 415-429

[3] E. M., Granger, J. C., Heurtley (1973).Visual chromaticitymodulation transfer function, Journal of the Optical Society of America 63, pp. 1173

[4] Q., Yu, K.J., Parker(1997). Stochastic Screen Halftoning for Electronic Imaging Devices, Journal of Visual Communication and Image Representation 8 (4), pp. 423440

[5] M., Orfanidou, S., Triantaphillidou, E., Allen(2008). Predicting image quality using a modular image difference model, Proceedings of SPIE - The International Society for Optical Engineering, 6808, art. no. 68080F

[6] D. H., Kelly(1983). Spatiotemporal variation of chromatic and achromatic contrast thresholds, Journal of the Optical Society of America 73, pp. 742

[7] M.D., Fairchild, G.M., Johnson(2004).iCAM framework for image appearance, differences, and quality,Journal of Electronic Imaging 13 (1), pp. 126-138.

[8] M. D. Fairchild(2005).Color Appearance Models, 2nd Ed., Wiley-IS\&T, Chichester, UK

[9] G.M., Johnson,X., Song, E.D., Montag, M.D.,
Fairchild(2010).Derivation of a color space for image color difference measurement,Color Research and Application 35 (6), pp. 387-400.

[10] M.J., Luque, P., Capilla, M.D., De Fez, M.C., GarcíaDomene (2010).Images perceived after chromatic or achromatic contrast sensitivity losses,Optometry and Vision Science 87 (5), pp. E313-E322

[11] K.J., Kim, R., Mantiuk, K.H., Lee (2013).Measurements of achromatic and chromatic contrast sensitivity functions for an extended range of adaptation luminance,Proceedings of SPIE - The International Society for Optical Engineering 8651, art. no. 86511A

[12] K., Hirai, T., Mikami, N., Tsumura, T., Nakaguchi(2010). Measurement and Modeling of Chromatic Spatio-Velocity Contrast Sensitivity Function and its Application to Video Quality Evaluation, Color Imaging Conference, pp. 86-91

[13] E., Harper, E.M., Granger, F., Sigg (2001).An investigation into the relationship between contrast and resolution of a printing system using the RIT contrast resolution test target,Proceedings of the Technical Association of the Graphic Arts, TAGA, pp. 671-684

[14] K., Samu, K., Wenzel, K., Ladunga (2001).Colour and luminance contrast sensitivity function of people with anomalous colour vision,Proceedings of SPIE - The International Society for Optical Engineering, 4421, pp. 351-354

[15] CIE (1998). Methods for deriving colour differences in images, tech. rep. Technical Committee TC 1-29 (CIE)

[16] G.M., Johnson, M.D. Fairchild(2002). On Contrast Sensitivity in an Image Difference Model,Society for Imaging Science and Technology: Image Processing, Image Quality, Image Capture, Systems Conference, pp. $18-23$

\section{Izvod}

\section{UTICAJ PROMENE HROMATSKOG KONTRASTA DIGITALNIH OTISAKA NA FUNKCIJU OSETLJIVOSTI OKA NA CONTRAST}

Milana Ž Sadžakov, Igor Đ Karlović

Fakultet tehničkih nauka, Katedra za grafičko inženjerstvo i dizajn, NoviSad, Srbija

Opažanje boje nekog stimulusa zavisi od njegovih prostornih i vremenskih karakteristika. U štampi se pomoću kolorimetrijske i prostorne varijacije rasterskih tačaka dolazi do određenog tona boje. Prostorne i temporalne karakteristike ljudskog vida se obično izražavaju preko funkcije osetljivosti oka na kontrast (CSF). Kontrasna funkcija osetljivosti oka u oftamologiji smatra se analognom funkciji prenosa transformacije (MTF) u optici. CSF je bitna za percepciju detalja i zbog toga predstavlja jednu od glavnih komponenti vizuelnih modela i metrike. Ispitivanja CSF su uglavnom vršena na ekranima u boji, međutim CSF nije dovoljno istražena u pogledu primene na uzorcima štampanim digitalnom štampom. Cilj ovoga rada bio je da se utvrdi da li postoji sličnost između dve vrste promene kontrasta: (1) tip C1 gde se kontrast smanjuje mešanjem dve oponentne boje i (2) tip C2 gde se kontrast smanjuje smanjivanjem zasićenosti svake od boja u jednakoj količini. Ispitivanje je vršeno na grupi od 15 ispitanika koji su pomoću lupe ocenjivali štampane test karte koje se sastoje iz polja na kojima variraju kontrast i prostorna frekvencija. Rezultati pokazuju da je osetljivost oka slična za obe vrste promene kontrasta. Grafik sa promenom u zasićenosti (C2) pokazuje manje vrednosti od grafika C1, pogotovo kod crveno-zelenog kontrasta. Ovo istraživanje može biti korisno za izradu budućih formula koje proračunavaju razlike u boji, kao i za prilagođavanje grafičkih dizajnova mogućnostima posmatrača da uoči sitne detalje i mali kontrast.
(ORIGINALNI NAUČNI RAD)

UDC 681.784.4:535.6

Ključne reči: funkcija osetljivosti oka na kontrast, CSF, hromatski kontrast, zasićenost boja 